\title{
Quality Changes of Different Sweet Cherry Cultivars at Various Stages of the Supply Chain
}

\author{
Fatih SEN*, Rustu Efe OKSAR, Mina GOLKARIAN, Sevde YALDIZ \\ Ege University, Faculty of Agriculture Department of Horticulture 35100 Bornova, İzmir, Turkey; fsenmacar@gmail.com (*correspondingauthor))
}

\begin{abstract}
Transportation of sweet cherry fruits to distant markets and further marketing processes often takes approximately 2-3 weeks. The present study investigates the quality changes during this time period at three stages for three sweet cherry cultivars: 'Early Burlat', 'Napoleon', and '0900 Ziraat'. Following pre-cooling, the sweet cherries were placed in modified atmosphere packages and exposed to the following stages for the indicated durations: transportation $(\mathrm{T})\left[8\right.$ days at $2{ }^{\circ} \mathrm{C}$ and $85 \%$ relative humidity $(\mathrm{RH})$ ]; distribution center (DC) (4 days at $6.5^{\circ} \mathrm{C}$ and $80 \% \mathrm{RH}$ ), and shelf-life $(\mathrm{SL})\left(2 \mathrm{days}\right.$ at $19{ }^{\circ} \mathrm{C}$ and $70 \% \mathrm{RH}$ ). Weight losses at the end of the SL stage were 3.11, 3.18, and 2.74\%, respectively in 'Early Burlat', 'Napoleon' and '0900 Ziraat'. Fruit firmness decreased after SL as compared to that at other stages and was more remarkable in ' 0900 Ziraat'. Decreased Chroma values which indicates, the intensity or color saturation were observed in all cultivars, whereas decreased hue angle values colours expressed in degrees were observed in the 'Early Burlat' and '0900 Ziraat'. In addition, a decrease was noted in the titratable acidity of all cultivars at the end of SL. The total soluble solids, total phenolic content, and antioxidant activities were similar for all cultivars at all stages. The visual appearance scores of 'Early Burlat' cherries decreased at the end of SL, because of development of pitting on the fruit surface. The fruit quality changes were limited at $\mathrm{T}$ and DC stages; however, these changes became more distinctive during the SL period. It was thus concluded that the SL duration and conditions were of the highest significance with regard to maintenance of the sweet cherry fruit quality.
\end{abstract}

Keywords: antioxidants, firmness, marketing, pitting, Prunus avium L., transportation

\section{Introduction}

Sweet cherry is a member of the genus Prunus and generally grows in mild climates. It is a fleshy and nonclimacteric fruit. The properties of sweet aroma, pleasant color, shape, high antioxidant activity, and nutritional content together enhance the consumer demand for sweet cherries. Accordingly, there is a rapid increase in sweet cherry production and global production sites parallel to the consumer demands. Turkey ranks first in the world's sweet cherry production (Anonymous, 2014). Higher cherry consumption plays a significant role in the prevention of diseases and maintenance of a healthy life. The health benefits of sweet cherry are linked to strong antioxidant activities (Yoo et al., 2010). The antioxidant capacities of sweet cherry fruits depend on the presence of phenolic compounds such as anthocyanins and melatonin (Burkhardt et al., 2001; Vinson et al., 2001). Phenolic antioxidants have several positive effects on human health such as the anticarcinogenic and anti-inflammatory effects (Usenik et al., 2008). The cultivar type and post-harvest conditions have direct impacts on antioxidant activities and phenolic contents of sweet cherries. While the total phenolic content of 'Van' and 'Tragana' cultivars increases, that of 'Burlat' does not significantly change during storage (Esti et al., 2002).
Due to their high respiration rate, minimal reserve carbohydrates, and high susceptibility to mechanical damage, sweet cherries are highly perishable (Kupferman and Sanderson, 2001). Adverse conditions during transportation and marketing of sweet cherries may hinder the supply of high-quality fruits to consumers. Losses in weight, firmness, color, aroma, and acidity as well as desiccation and browning or discoloration of the green stem of the sweet cherry are some of the major quality losses (Alique et al., 2005; Bernalte et al., 2003). Susceptibility to fungal rotting, a high transpiration rate, and vulnerability to physiological disorders such as bruising and pitting aggravate the deterioration of sweet cherry fruits (Alique $e t$ al., 2005). Therefore, optimum conditions specific to the cultivar should be provided throughout the entire marketing chain of this fruit to protect its quality. Optimization of harvesting, handling, processing, packaging, storing, transporting, distribution, and marketing conditions play highly significant roles in quality preservation. Modified atmosphere packaging (MAP) technology has been successfully used to maintain the postharvest quality and to prolong the storage period of several fresh fruits and vegetables. MAP technology is more effective in combination with cooling and enables 
preservation of the fruit color and brightness and greenness of the stalks as well as reduces weight loss, fruit damage, and spoilage during transport and marketing activities (Kader and Watkins, 2000; Singh et al., 2012; Wani et al., 2014).

As sweet cherries are perishable fruits, relevant attention and great care should be taken while transporting them to distant markets so as to supply quality fruits to the consumers. In some cases, retail chains are not equipped to provide proper conditions to preserve the fruits (Wani et al., 2014). Temperature and relative humidity $(\mathrm{RH})$ are critical factors that influence the quality of sweet cherries during postharvest storage (Yaman and Bayindirli, 2002). Although these two factors are controlled during the storage and transportation processes, it is difficult to adjust them, especially to regulate the $\mathrm{RH}$ at the distribution centers and during sales at retailers (Wani et al., 2014). Optimum storage conditions of sweet cherries were reported as $0^{\circ} \mathrm{C}$ temperature and 90-95\% RH (Bernalte et al., 1999). Despite several studies on the storage of sweet cherries, only a few articles simulated the transportation and marketing stages of the supply chain, and additionally the results were controversial perhaps due to the varietal and agro-ecological differences (Wang and Long, 2014). The present study is the first on major cherry cultivars that are exported to distant markets. The cultivar '0900 Ziraat' constitutes a significant proportion cherries traded of the worldwide (Demirtas and Sarisu, 2011).

The present study was conducted to investigate the changes in the physical, chemical, and sensory characteristics of 'Early Burlat', 'Napoleon', and '0900 Ziraat' cherry cultivars during their transportation $(T)$, storage at the distribution centers (DC; wholesalers), and shelf-life (SL; retailers) stages.

\section{Materials and methods}

\section{Fruit material and supply chain trial}

The experiment was conducted in 2013 on fruits harvested from 13-year-old 'Early Burlat', 'Napoleon', and '0900 Ziraat' sweet cherry trees (Prunus avium L.) grafted onto 'Prunus mahaleb' rootstock in Kemalpasa, Izmir Province, Turkey. 'Early Burlat', 'Napoleon', and '0900 Ziraat' sweet cherry fruits were harvested at full-ripe stage $(08,22$, and 29 May, respectively) and hydro-cooled (fruit pulp temperature at $1-2^{\circ} \mathrm{C}$ ) the same day. Fruits of uniform size (26-28 $\mathrm{mm}$ diameter) that were disease-free and without other defects were selected, put into modified atmosphere packages, and the packages were sealed tightly. MAP were placed into cardboard boxes and subjected to the following stages: a) transportation ( $\mathrm{T} ; 8$ days at $2 \pm 0.5^{\circ} \mathrm{C}$ and $85 \pm 5 \% \mathrm{RH}$ ) that included the pre-stage at the packing house; b) distribution center (DC; 4 days at $6.5 \pm 0.5^{\circ} \mathrm{C}$ and $80 \pm 5 \% \mathrm{RH}$ ), and c) shelf life (SL; 2 days at $19 \pm 0.5$ ${ }^{\circ} \mathrm{C}$ and $70 \pm 5 \% \mathrm{RH}$ ) to simulate the real conditions faced during marketing.

Considering the actual transportation to distant markets (e.g., from Turkey to the United Kingdom) and distribution centers and the prevailing marketing conditions, the duration of exposure and ambient conditions were defined. Fruit samples were collected at the end of each stage and subjected to physical, chemical, and sensory analyses. The research was designed as a randomized block design with 5 replications and each MAP package (3 $\mathrm{kg}$ of cherry fruits) was considered as a single replication.

\section{Quality attributes}

The sweet cherry samples were weighted at the initial phase and at the end of the T, DC and SL stages on an electronic scale (XB 12100, 0.05 g accuracy), and weight loss was determined and expressed as the percent lost from the initial weight.

Fruit firmness was determined on 25 cherry fruit per replicate by using a penetrometer (FT 011) using a 4.0-mm diameter head and conical-shaped spear; the results were expressed in Newtons $(\mathrm{N})$.

The external skin color was measured at the equatorial level on both sides of the 25 sweet cherry fruits by using a colorimeter (CR-300), and the average scores were recorded in terms of CIE- $L^{*} a^{*} b^{*}$ values. These values were then used to calculate

Chroma $\left(C^{*}=\left[a^{* 2}+b^{* 2}\right]^{1 / 2}\right)$,

which indicates the intensity or color saturation and hue angle $\left(b^{\circ}=\tan ^{-1}\left[b^{*} / a^{*}\right]\right)$ that is expressed in degrees and represents: $0^{\circ}$ (red-purple), $90^{\circ}$ (yellow), $180^{\circ}$ (bluishgreen), and $270^{\circ}$ (blue) (McGuire, 1992).

Juice was extracted from 25 cherry fruits per replicate for further analysis. The total soluble solid (TSS) content of the fruit juice was determined by using a digital refractometer (PR-1) and expressed in percent. The titratable acidity (TA) was determined by titrating $10 \mathrm{~mL}$ of juice with $0.1 \mathrm{~N}$ $\mathrm{NaOH}$ up to $\mathrm{pH}$ 8.1. The results were expressed as grams malic acid per $100 \mathrm{~mL}$ of fruit juice, in accordance with the AOAC standards (1984).

\section{Total phenolic content and antioxidant activity}

Fruit extracts were prepared from 10 fruits according to Thaipong et al. (2006), with some modifications for total phenolic content and antioxidant activity (in methanol extract) analysis. Total phenolic content was determined by the Folin-Ciocalteu method according to the method of Swain and Hillis (1959), with an incubation time of 120 minutes for color development. The absorbance was measured at $725 \mathrm{~nm}$ using a spectrophotometer and the results were expressed as milligram gallic acid equivalent (GAE) per 100 gram of fresh weight $(\mathrm{FW})$ with reference to a gallic acid $(0-0.1 \mathrm{mg} / \mathrm{mL})$ standard curve.

The ferric reducing ability of plasma (FRAP) assay was performed as previously described by Benzie and Strain (1996), where reductants ("antioxidants") in the sample reduce $\mathrm{Fe}$ (III)/tripyridyltriazine complex to a blue ferrous form, with an increase in the absorbance at $593 \mathrm{~nm}$. The final results are expressed in $\mu$ mol trolox equivalents (TE)/g $\mathrm{FW}$, with reference to a trolox $(25-500 \mu \mathrm{mol})$ standard curve.

\section{Decay development}

Decay development was examined on $3 \mathrm{~kg}$ fruit sample and their rates were expressed in percent. 
503

\section{Sensory evaluation}

The sensory quality evaluation of appearance was conducted by an experienced six-member panel on a ninepoint hedonic scale: appearance (9: displays the complete characteristics of the sweet cherry appearance at harvest; 7 : good appearance; 5: acceptable appearance, slight pitting; 3: poor appearance, moderate pitting; 1: high pitting, decay and/or stem desiccation). The procedures for sensory evaluation of horticultural crops described by Heintz and $\operatorname{Kader}(1983)$ were utilized by the panelists.

\section{Statistical analysis}

All data were subjected to analyses of variance (ANOVA) by using the IBM SPSS Statistics 19 statistical software. Significant differences between the means for each sweet cherry cultivars were determined by Duncan's multiple range tests at $\mathrm{p}<0.05$. Standard deviation of the mean (SD) was also calculated from the replicates.

\section{Results and discussion}

Weight loss and fruit firmness values of cherry cultivars during the transport and marketing stages are presented in Fig. 1. The increases observed in the weight loss of cherry cultivars during $\mathrm{T}\left(8\right.$ days at $\left.2{ }^{\circ} \mathrm{C}\right), \mathrm{DC}\left(4\right.$ days at $\left.6.5^{\circ} \mathrm{C}\right)$, and SL $\left(2\right.$ days at $\left.19^{\circ} \mathrm{C}\right)$ stages were found to be significant $(p<0.01)$. Such increases became especially distinctive after the SL stage. At the end of all stages, the weight loss in 'Early Burlat', 'Napoleon', and '0900 Ziraat' cherry cultivars were observed as $3.11,3.18$, and $2.74 \%$, respectively (Fig. 1a). Lower weight loss in the $\mathrm{T}$ and $\mathrm{DC}$ stages were mainly because of the use of MAP packages (Kucukbasmaci et al., 2008; Singh et al., 2012; Wani et al., 2014) and the limited moisture loss due to ambient conditions (temperature and $\mathrm{RH}$ ). Weight loss during the SL stage was higher than that at the $\mathrm{T}+\mathrm{DC}$ stages when the MAP packages were open,

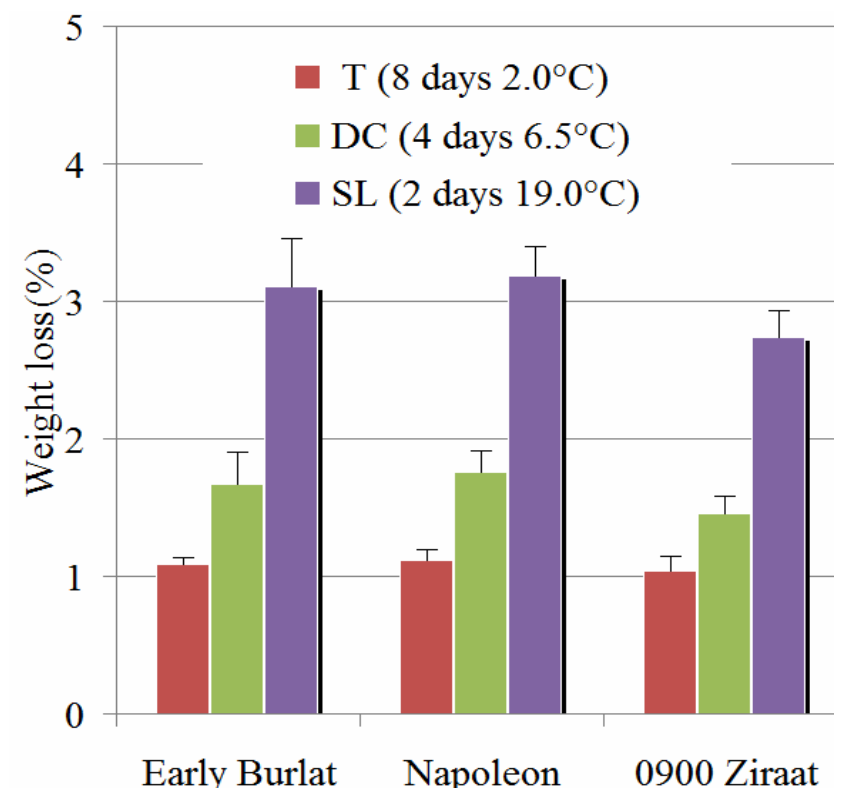

ambient temperature was high $\left(19^{\circ} \mathrm{C}\right)$, and $\mathrm{RH}$ was low (70\%) during SL for 2 days. Similarly, the weight loss observed in the '0900 Ziraat' cherry cultivar during 6 weeks of storage was lower than that in 2 days of $\mathrm{SL}$ at $20^{\circ} \mathrm{C}$ (Onursal et al., 2013). Weight loss of the '0900 Ziraat' cherry cultivar at the end of SL stage was $13 \%$ lower than that of the other cultivars. Variations in weight loss of the different cherry cultivars in this study comply with those in previous reports (Diaz-Mula et al., 2010), irrespective of the difference in the skin characteristics and composition of the fruits.

Fruit firmness is directly related to storage potential, mechanical resistance, and rot development (Esti et al., 2002). The decreases observed in firmness of all three cherry cultivars during the transport and marketing stages were significant $(\mathrm{p}<0.01)$. Fruit firmness of 'Early Burlat', 'Napoleon' and '0900 Ziraat' cultivars were observed to be 9.9, 10.2, and 11.9 N, respectively, at harvest (Fig. 1b). While fruit firmness of 'Early Burlat' and '0900 Ziraat' after $\mathrm{DC}$ were similar to that after $\mathrm{T}$, there was a decrease in fruit firmness of 'Napoleon'. Fruit firmness of the cherry cultivars exhibited a decrease after SL as compared to that in the other stages. At the end of SL and compared to the initial firmness values, there were 19.8, 21.2, and $16.5 \%$ decreases, respectively, in 'Early Burlat', 'Napoleon', and '0900 Ziraat' cherry fruit. Fruits began to soften following rapid loss of moisture from the surface (Wani et al., 2014). The decreases in firmness during the transportation and marketing processes also resulted from moisture loss. Meheriuk et al. (1995) reported significant losses in firmness of 'Lapins' cherry cultivar during storage. Similarly, decreasing firmness values were also reported for other cherry cultivars (Kappel et al., 2002; Clayton et al., 2003; Onursal et al., 2013; Wang and Long, 2014). At all stages, fruit firmness of '0900 Ziraat' was about $16.5 \%$ higher than that of the other cultivars. Differences in fruit firmness among cultivars indicate the differences in their cell structures, skin characteristics, compositions and/or respiration rates (Karacali, 2012).

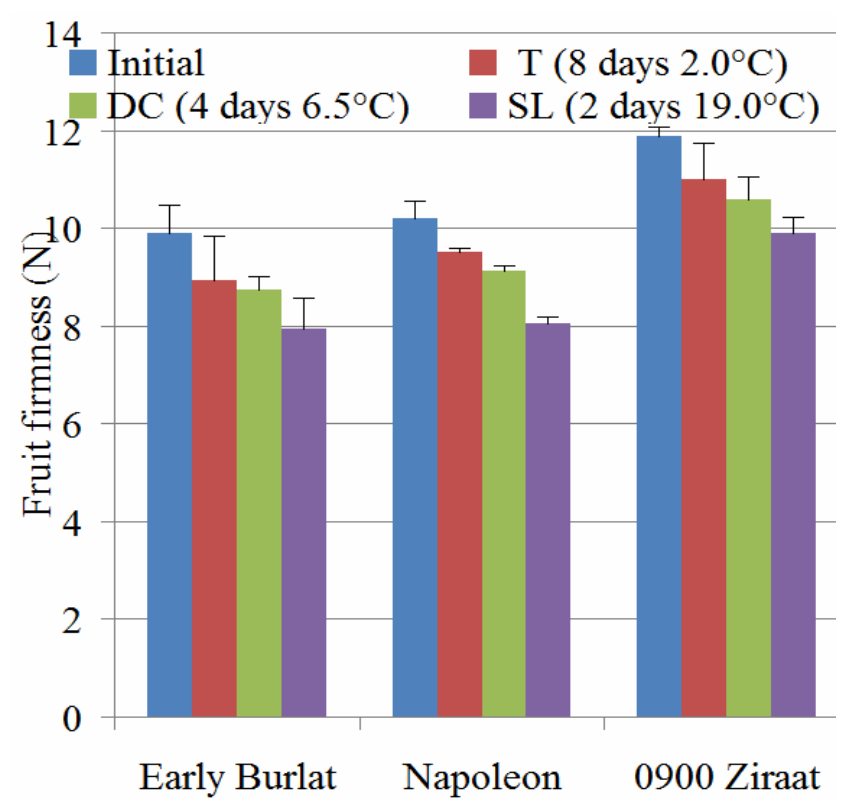

Fig. 1. Postharvest weight loss (a-left) and flesh firmness (b-right) values of 'Early Burlat', 'Napoleon', and '0900 Ziraat' cherry cultivars at three different stages of the supply chain 
Tab. 1. Postharvest TSS and TA content of 'Early Burlat', 'Napoleon', and '0900 Ziraat' cherry cultivars at three different stages of the supply chain

\begin{tabular}{ccccccc}
\hline \multirow{2}{*}{ Sampling stage } & \multicolumn{3}{c}{ TSS content $(\%)$} & \multicolumn{2}{c}{ TA content $(\mathrm{g}$ malic acid $/ 100 \mathrm{~mL})$} \\
\cline { 2 - 6 } & 'Early Burlat' & 'Napoleon' & '0900 Ziraat' & 'Early Burlat' & 'Napoleon' & '0900 Ziraat' \\
\hline Initial & $14.97^{\mathrm{NS}}$ & $14.97^{\mathrm{NS}}$ & $16.50^{\mathrm{NS}}$ & $0.91 \mathrm{a}^{\mathrm{z}^{*}}$ & $0.88 \mathrm{a}^{* *}$ & $0.99 \mathrm{a}$ \\
$\mathrm{T}\left(8\right.$ days, $\left.2.0^{\circ} \mathrm{C}\right)$ & 15.17 & 15.06 & 16.69 & $0.86 \mathrm{ab}$ & $0.86 \mathrm{a}$ & $0.92 \mathrm{~b}$ \\
$\mathrm{DC}\left(4\right.$ days, $\left.6.5^{\circ} \mathrm{C}\right)$ & 15.23 & 15.23 & 16.97 & $0.79 \mathrm{bc}$ & $0.86 \mathrm{a}$ & $0.93 \mathrm{~b}$ \\
$\mathrm{SL}\left(2\right.$ days, $\left.19.0^{\circ} \mathrm{C}\right)$ & 15.17 & 15.27 & 17.13 & $0.72 \mathrm{c}$ & $0.79 \mathrm{~b}$ & $0.88 \mathrm{c}$ \\
\hline
\end{tabular}

NS, ,", Nonsignificance or significance at $\mathrm{p}<0.05$ or 0.01 , respectively

${ }^{7} \mathrm{Means}$ for each experiment were separated by different letters within columns by Duncan's multiple-range test, $\mathrm{p}<0.05$

The changes in $C^{*}$ and $h$ values of different cherry cultivars during the transportation and marketing phases are presented in Fig. 2. The decreases in $C^{*}$ values of the 'Early Burlat' cultivar at T and SL stages and decrease in $C^{*}$ values of '0900 Ziraat' at the end of SL were statistically significant $(\mathrm{p}<0.01)$. The decrease in $C^{*}$ values of 'Early Burlat', 'Napoleon', and '0900 Ziraat' cherry fruit during the SL stage were calculated as 15.7, 13.6, and 7.8\%, respectively. The changes in $b^{\circ}$ values of 'Early Burlat' and '0900 Ziraat' cultivars were similar to the changes observed in $C^{*}$ values and the decreases at the end of SL were found to be significant $(\mathrm{p}<0.05)$. The changes in $b^{\circ}$ values of 'Napoleon' cherries were highly limited and varied between 14.53 and $15.75 \%$. The changes in fruit color parameters during the transportation and marketing phases are proportional to the ripening of the fruits. Decreased brightness values were also found in 'Lapins' cherry cultivar during the storage period (Meheriuk et al., 1995). Distinctive changes were not observed in color values of cherries since the fruits were harvested at a fully ripe stage. Color darkening and increased anthocyanin contents were reported for cherries harvested at different ripening stages during storage and shelf life, based on the cultivar and ripening stage (Serrano et al., 2009).

Changes in TSS and TA contents of the cherries during the transportation and marketing stages are given in Tab. 1 . It has been reported that TSS and TA contents are related to the intensity of sweet cherry flavor and that consumer

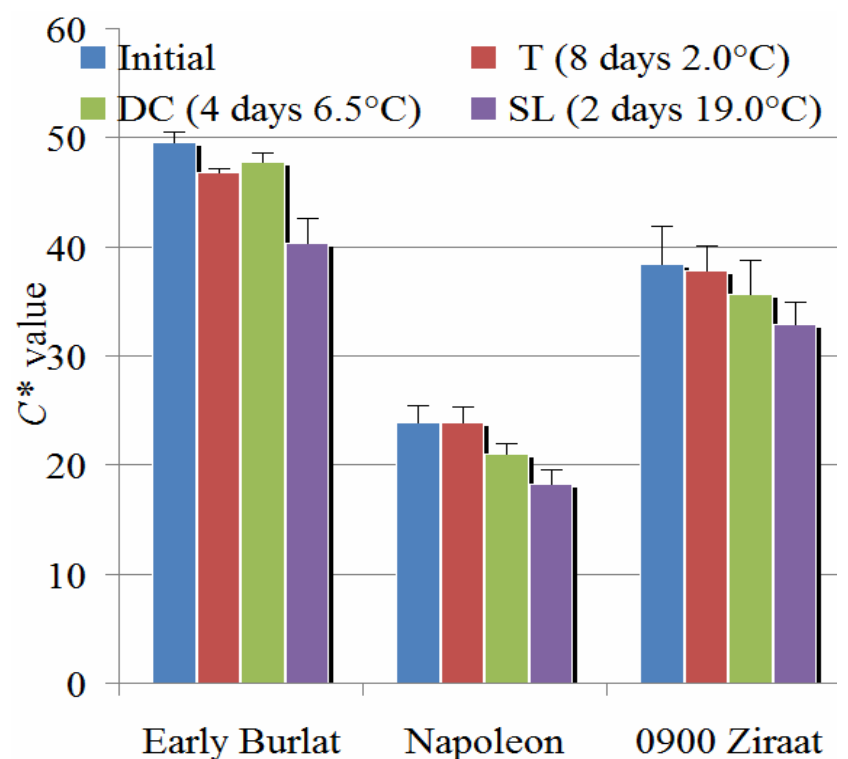

acceptability increases with high TSS and TA levels in the fruit (Crisosto et al., 2003; Kalyoncu et al., 2009). TSS contents of 'Early Burlat', 'Napoleon', and '0900 Ziraat' cherry cultivars during transportation and marketing stages exhibited similar tendencies and they were 15.0-15.2, 15.015.3, and $16.5-17.1 \%$, respectively (Tab. 1). Similar to the findings of the present study, significant changes were not observed in the TSS contents of cherries during the MAP storage of fruits (Meheriuk et al., 1995; Meheriuk et al., 1997; Remon et al., 2000; Onursal et al., 2012). The higher TSS contents of ' 0900 Ziraat' cultivar was mainly due to the cultivar type. Girard and Kopp (1998) reported that the TSS contents of 12 different cherry cultivars ranged between 13.5 and $24.5 \%$. Several other studies also reported significantly different TSS contents for different sweet cherry cultivars (Kappel et al., 2002; Diaz-Mula et al., 2010).

The decreases in TA values of cherries before the SL stage were significant $(\mathrm{p}<0.01)$. Such decreases were especially remarkable in the 'Early Burlat' variety (21\%). The post-harvest decreases in TA values are proportional to the ripening of the fruits. Similar decreases in TA values were also reported during the storage of '0900 Ziraat' (Kucukbasmaci et al., 2008; Onursal et al., 2013), 'Napoleon' (Esturk et al., 2014), 'Burlat' (Remon et al., 2000), 'Sciazza', 'Ferrovia' (Esti et al., 2002), and 'Lapins' (Meheriuk et al., 1995) cultivars. These decreases are closely related to the ripening level at harvest, storage conditions, and durations (Wani et al., 2014). As sweet cherry fruit is a

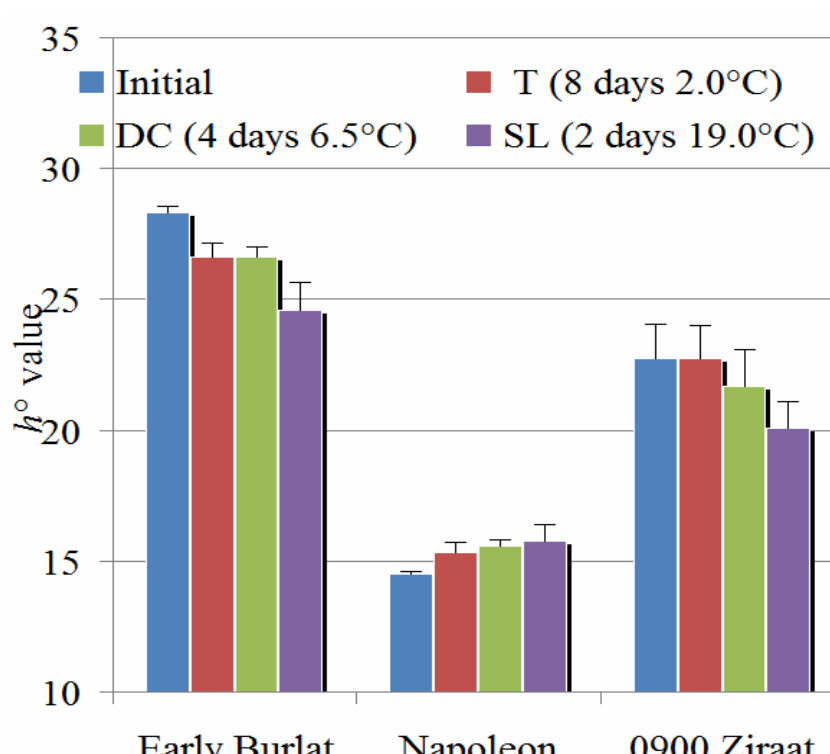

Fig. 2. Postharvest $C^{*}$ (a-left) and $b^{\circ}$ values (b-right) of 'Early Burlat', 'Napoleon', and '0900 Ziraat' cherry cultivars at three different stages of the supply chain 
Tab. 2. Post-harvest total phenolic content and antioxidant activity of 'Early Burlat', 'Napoleon', and '0900 Ziraat' cherry cultivars at three different stages of the supply chain

\begin{tabular}{ccccccc}
\hline Sampling stage & \multicolumn{2}{c}{ Total phenolic content $(\mathrm{mg} \mathrm{GAE} / 100 \mathrm{~g} \mathrm{FW})$} & \multicolumn{3}{c}{ Antioxidant activity $(\mu \mathrm{mol} \mathrm{TE} / \mathrm{g} \mathrm{FW})$} \\
\cline { 2 - 7 } & 'Early Burlat' & 'Napoleon' & '0900 Ziraat' & 'Early Burlat' & 'Napoleon' & '0900 Ziraat' \\
\hline Initial & $101.3^{\mathrm{NS}}$ & $103.5^{\mathrm{NS}}$ & $94.6^{\mathrm{NS}}$ & $9.22^{\mathrm{NS}}$ & $13.32^{\mathrm{NS}}$ & $7.93^{\mathrm{NS}}$ \\
$\mathrm{T}\left(8\right.$ days, $\left.2.0^{\circ} \mathrm{C}\right)$ & 95.7 & 106.5 & 95.0 & 8.38 & 13.27 & 7.49 \\
$\mathrm{DC}\left(4\right.$ days, $\left.6.5^{\circ} \mathrm{C}\right)$ & 99.5 & 106.8 & 94.5 & 9.42 & 14.10 & 7.18 \\
SL $\left(2\right.$ days, $\left.19.0^{\circ} \mathrm{C}\right)$ & 102.2 & 102.6 & 88.0 & 9.21 & 12.25 & 6.75 \\
\hline
\end{tabular}

NS, Nonsignificant

non-climacteric fruit, loss in TA tends to occur simultaneously with metabolic activities.

Total phenolic content and antioxidant activity of cherry fruit at harvest and at T, DC, and SL stages are presented in Tab. 2. Significant differences were observed in the total phenolic content and antioxidant activity of the tested cherry cultivars during the transportation and marketing stages. The average total phenolic contents of 'Early Burlat', 'Napoleon', and '0900 Ziraat' cultivars during the transport and marketing processes were 99.7, 104.9, and $93.0 \mathrm{mg} \mathrm{GAE} / 100 \mathrm{~g} \mathrm{FW}$, and the antioxidant activities were 9.06, 13.24, and $7.34 \mu \mathrm{mol} \mathrm{TE} / \mathrm{g} \mathrm{FW}$, respectively. Harvest at fully ripe stage resulted in limited changes in the total phenolic content and antioxidant activity. Serrano $e t$ al. (2009) reported increased post-harvest total phenolic and antioxidant activity values for cherries based on the ripening levels. Functional parameters reached the maximum levels with 2-day delay in harvest (Diaz-Mula $e t$ al., 2010). Total phenolic content and especially the antioxidant activity of 'Napoleon' were significantly higher than those of '0900 Ziraat' cultivar. Previous studies also reported significantly different results for different sweet cherry cultivars (Usenik et al., 2008; Serrano et al., 2009; Diaz-Mula et al., 2010; Kelebek and Selli, 2011).

Decay development was not observed in 'Early Burlat', 'Napoleon' or '0900 Ziraat' cherry fruit during the transportation and marketing stages. However, storage in MAP, climatic conditions during the growth, cultural practices, and disease and pest management practices had significant impacts on rot development.

Visual appearance scores of cherry fruits and stems at the end of $\mathrm{T}$ and DC stages were similar to the initial scores. The difference in the decrease in the visual appearance of 'Napoleon' and '0900 Ziraat' cherry fruit at the end of SL stage were not significant. On the other hand, such decreases were found to be significant $(p<0.01)$ in 'Early Burlat' (Tab. 3) mainly because of development of pitting over the fruit skin at the end of SL stage. Stems of all

Tab. 3. Postharvest visual appearance of 'Early Burlat', 'Napoleon', and '0900 Ziraat' cherry cultivars at three different stages of the supply chain

\begin{tabular}{cccc}
\hline $\begin{array}{c}\text { Sampling } \\
\text { stage }\end{array}$ & $\begin{array}{c}\text { 'Early } \\
\text { Burlat' }\end{array}$ & 'Napoleon' & $\begin{array}{c}\text { '0900 } \\
\text { Ziraat' }\end{array}$ \\
\hline Initial & $9.0 \mathrm{a}^{z^{* *}}$ & $9.0^{\mathrm{NS}}$ & $9.0^{\mathrm{NS}}$ \\
$\mathrm{T}\left(8\right.$ days, $\left.2.0^{\circ} \mathrm{C}\right)$ & $9.0 \mathrm{a}$ & 9.0 & 9.0 \\
$\mathrm{DC}\left(4\right.$ days, $\left.6.5^{\circ} \mathrm{C}\right)$ & $8.2 \mathrm{a}$ & 8.6 & 9.0 \\
$\mathrm{SL}\left(2\right.$ days, $\left.19.0^{\circ} \mathrm{C}\right)$ & $5.8 \mathrm{~b}$ & 7.8 & 8.2 \\
\hline
\end{tabular}

NS, , Nonsignificance or significance at $\mathrm{p}<0.01$.

${ }^{2}$ Means for each experiment were separated within columns by Duncan's multiplerange test, $p<0.05$ cultivars preserved their green color and brightness during the $T$ and DC stages because limited water loss occurred from the fruits and stems during these stages. Storage in MAP was effective in limiting water loss from the stems (Kucukbasmaci et al., 2008; Singh et al., 2012; Wani et al., 2014). Very slight browning or discoloration of the green stem was observed at the end of SL stage.

\section{Conclusion}

Changes in the quality parameters of cherry cultivars were more remarkable during the 2-day SL period as compared to the 8-day $\mathrm{T}$ period or the 4-day DC period. While '0900 Ziraat' and 'Napoleon' cultivars showed preserved quality at the end of SL stages, some 'Early Burlat' fruits showed visible spoilage. With regard to the investigated quality parameters, '0900 Ziraat' cherry cultivar was found to be superior over the others. The present results clearly indicate the significance of the SL conditions and/or durations for preservation of the sweet cherry quality.

\section{Acknowledgement}

The authors wish to extend their thanks to Dr. Belit Balci from Alara, Turkey for his valuable inputs and comments.

\section{References}

Alique R, Zamorano JP, Martinez MA, Alonso J (2005). Effect of heat and cold treatments on respiratory metabolism and shelflife of sweet cherry, type picota cv. 'Ambrunes'. Postharvest Biol Tec 35:153-165.

Anonymous (2014). Food and Agriculture Organization of the United Nations. Available at: http://faostat.fao.org (Accessed March 16, 2014).

Kucukbasmaci F, Ozkaya O, Agar T, Saks Y (2008). Effect of retail-size modified atmosphere packaging bags on postharvest storage and shelf-life quality of ' 0900 Ziraat' sweet cherry. Acta Hortic 795:775-780.

Benzie IEF, Strain JJ (1996). The ferric reducing ability of plasma (FRAP) as a measure of "antioxidant power": the FRAP assay. Anal Biochem 239:70-76.

Bernalte MJ, Hernandez MT, Vidal-Aragon MC, Sabio E (1999). Physical, chemical, flavor and sensory characteristics of two sweet cherry varieties grown in 'Valle del Jerte' (Spain). J Food Quality 22:403-416.

Bernalte MJ, Sabio E, Hernandez MT, Gervasini C (2003). 
Influence of storage delay of Van sweet cherry. Postharvest Biol Tec 28:303-312.

Burkhardt S, Tan DX, Manchester LC, Hardeland R, Reiter RJ (2001). Detection and quantification of the antioxidant melatonin in Montmorency and Balaton tart cherries (Prunus cerasus). J Agr Food Chem 49:4898-4902.

Crisosto CH, Crisosto GM, Metheney P (2003). Consumer acceptance of Brooks and Bing cherries is mainly dependent on fruit SSC and visual skin colour. Postharvest Biol Tec 28:159-167.

Clayton M, Biasi WV, Agar IT, Southwick SM, Mitcham EJ (2003). Postharvest quality of 'Bing' cherries following preharvest treatment with hydrogen cyanamide, calcium ammonium nitrate, or gibberellic acid. J Hortic Sci 38:407411.

Demirtas I, Sarisu HC (2011). Cherry Cultivation. Ministry of Food, Agriculture and Livestock Fruit Research Station, Isparta, Turkey 11:1-12.

Diaz-Mula HM, Castillo S, Martinez-Romero D, Valero D, Zapata PJ, Guillen F, Serrano M (2010). Sensory, nutritive and functional properties of sweet cherry as affected by cultivar and ripening stage. Food Sci Technol Int doi: $10.1177 / 1082013209351868$.

Esti M, Cinquanta L, Sinesio F, Moneta E, Mateo MD (2002). Physicochemical and sensory fruit characteristics of two sweet cherry cultivars after cool storage. Food Chem 76:399-405.

Esturk O, Ayhan Z and Ustunel MA (2014). Modified atmosphere packaging of 'Napoleon' cherry: effect of packaging material and storage time on physical, chemical, and sensory quality. Food Bioprocess Tech 5:1295-1304.

Girard B, Kopp TG (1998). Physicochemical characteristics of selected sweet cherry cultivars. J Agr Food Chem 46:471-476.

Heintz CM, Kader AA (1983). Procedures for the sensory evaluation of horticultural crops. J Hortic Sci 18:18-22.

Kader AA, Watkins CB (2000). Modified atmosphere packagingtoward 2000 and beyond. HortTechnology 10(3):483-486.

Kalyoncu IH, Ersoy N, Yilmaz M (2009). Some physicochemical properties and mineral contents of sweet cherry (Prunus avium L.) type grown in Konya. Afr J Biotechnol 8:27442749.

Kappel F, Toivonen P, McKenzie DL, Stan S (2002). Storage characteristics of new sweet cherry cultivars. J Hortic Sci 37:139-143.

Karacali I (2012). Storage and marketing of horticultural products. Ege University Agricultural Faculty Publication No: 494 İzmir, Turkey.

Kelebek H, Selli S (2011). Evaluation of chemical constituents and antioxidant activity of sweet cherry (Prunus avium L.) cultivars. Int J Food Sci Tech 46:2530-2537.

Kupferman G, Sanderson P (2001). Temperature management and modified atmosphere packing to preserve sweet cherry fruit quality. Acta Hort 667:523-528.
McGuire RG (1992). Reporting of objective color measurements. J Hortic Sci 27:1254-1255.

Meheriuk M, Girard B, Moyls L, Beveridge HJT, McKenzie DL, Harrison J, Weintraub $S$, Hocking R (1995). Modified atmosphere packaging of 'Lapins' sweet cherry. Food Res Int 28(3):239-244.

Meheriuk M, McKenzie B, Girard B, Molys AL, Weintraub S, Hocking R, Kopp T (1997). Storage of 'Sweetheart' cherries in sealed plastic film. J Food Quality 20:189-198.

Onursal CE, Calhan O, Eren I, Cetinbas M, Butar S, Demirtas I (2013). Effects of preharvest aminoethoxyvinylglycine (AVG) treatments on cold storage and shelf life quality of ' 0900 Ziraat'sweet cherry cultivar. J Agr Sci 6(1):91-96.

Ferrer A, Marquina P, Burgos J, Oria R (2000). Use of modified atmospheres to prolong the postharvest life of Burlat cherries at two different degrees of ripeness. J Sci Food Agr 80:15451552.

Serrano M, Diaz-Mula HM, Zapata PJ, Castillo S, Guillein F, Martinez-Romero D (2009). Maturity stage at harvest determines the fruit quality and antioxidant potential after storage of sweet cherry cultivars. J Agr Food Chem 57:32403246.

Singh P, Wani AA, Goyal GK (2012). Shelf life extension of fresh ready-to-bake pizza by the application of modified atmosphere packaging. Food Bioprocess Tech 5(3):1028-1037.

Swain T, Hillis WE (1959). The phenolic constituents of Prunus domestica I. The quantitative analysis of phenolic constituents. J Sci Food Agr 10:63-68.

Thaipong K, Boonprakob U, Crosby K, Cisneros-Zevallos L, Byrne DH (2006). Comparison of ABTS, DPPH, FRAP, and ORAC assays for estimating antioxidant activity from guava fruit extracts. J Food Compos Anal 19:669-675.

Usenik V, Fabcic J, Stampar F (2008). Sugars, organic acids, phenolic composition and antioxidant activity of sweet cherry (Prunus avium L.). Food Chem 107:185-192.

Vinson JA, Su X, Zubik L, Bose P (2001). Phenol antioxidants quantity and quality in foods: Fruits. J Agr Food Chem 49:5315-5321.

Wang Y, Long LE (2014). Respiration and quality responses of sweet cherry to different atmospheres during cold storage and shipping. Postharvest Biol Tec 92:62-69.

Wani AA, Singh P, Guld K, Wani MH, Langowski HC (2014). Sweet cherry (Prunus avium): Critical factors affecting the composition and shelf life. Food Packaging Shelf Life 1(1):8699.

Yaman O, Bayindirli L (2002). Effects of an edible coating and cold storage on shelf-life and quality of cherries. LWT-Food Sci Technol 35:146-150.

Yoo KM, Al-Farsi M, Lee H, Yoon H, Lee CY (2010). Antiproliferative effects of cherry juice and wine in Chinese hamster lung fibroblast cells and their phenolic constituents and antioxidants activities. Food Chem 123:734-740. 